\title{
Review
}

\section{ARSENIC PHYTOEXTRACTION AND HYPERACCUMULATION BY FERN SPECIES}

\author{
Maria Isidoria Silva Gonzaga*; Jorge Antonio Gonzaga Santos; Lena Qiying Ma \\ University of Florida - Soil and Water Science Department, PO Box 110510 - Gainesville, FL - USA - 32611-0290 \\ *Corresponding author<isis@ufba.br>
}

\begin{abstract}
Arsenic (As) is an ubiquitous trace metalloid found in all environmental media. Its presence at elevated concentrations in soils derives from both anthropogenic and natural inputs. Arsenic is a toxic and carcinogenic element, which has caused severe environmental and health problem worldwide. Technologies currently available for the remediation of arsenic-contaminated sites are expensive, environmentally disruptive, and potentially hazardous to workers. Phytoextraction, a strategy of phytoremediation, uses plants to clean up contaminated soils and has been successfully applied to arsenic contaminated soils. It has the advantage of being cost-effective and environmentally friendly. A major step towards the development of phytoextraction of arsenic-impacted soils is the discovery of the arsenic hyper accumulation in ferns, first in Pteris vittata, which presented an extraordinary capacity to accumulate 2.3\% arsenic in its biomass. Another fern, Pityrogramma calomelanos was found to exhibit the same hyperaccumulating characteristics. After that, screening experiments have revealed that the Pteris genus is really unique in that many species have the potential to be used in phytoextraction of arsenic. In general, these plants seem to have both constitutive and adaptive mechanisms for accumulating or tolerating high arsenic concentration. In the past few years, much work has been done to understand and improve the hyperaccumulating capability of these amazing plants. In particular, the field of molecular biology seems to hold the key for the future of the phytoremediation.
\end{abstract}

Key words: environmental contamination, hyperaccumulator plants, phytoremediation

\section{FITOEXTRAÇÃO E HIPERACUMULAÇÃO DE ARSÊNIO POR ESPÉCIES DE SAMAMBAIAS}

\begin{abstract}
RESUMO: O arsênio e um metalóide traço encontrado basicamente em todos os ambientes. Elevadas concentrações de arsênio no solo podem acontecer naturalmente devido ao intemperismo de rochas ricas em arsênio, como também de atividades antropogênicas. O arsênio é um elemento tóxico e cancerígeno. Em muitas partes do mundo, a contaminação pelo arsênio tem causado problemas ambientais e de saude. As técnicas disponíveis para a remediação do arsênio são economicamente proibitivas, destroem a paisagem natural e ainda podem afetar a saúde de pessoas diretamente envolvidas no processo. A fitoextração, uma das estratégias da fitoremediação, utiliza plantas para descontaminar solos e tem sido aplicada com sucesso em solos contaminados com arsênio e outros elementos. Dentre muitas vantagens, essa técnica tem baixo custo quando comparada com as convencionais. Um ponto chave no desenvolvimento da fitoextração foi a constatação de que samambaias hiperacumulam arsênio. Primeiro, em Pteris vittata, que apresentou extraordinária capacidade para remover arsênio do solo, concentrando 2.3\% do arsênio na biomassa. Em seguida, foi observado que a samambaia Pityrogramma calomelanos possui capacidade semelhante para acumular arsênio. Essa característica peculiar foi observada em outras samambaias do genero Pteris. Em geral, essas plantas parecem apresentar mecanismos constitutivos e adaptativos que permitem elevada absorção e sobrevivência em solos com altas concentrações de arsênio. Muitas pesquisas têm sido conduzidas no sentido de entender e aumentar a capacidade de aborção de arsênio dessas plantas. Em particular, a chave para a aplicação bem sucedida da fitoremediação parece estar na biologia molecular. Palavras-chave: contaminação ambiental, plantas hiperacumuladoras, fitoremediação
\end{abstract}

\section{INTRODUCTION}

Arsenic contamination in the environment from both anthropogenic and natural sources occurs in many parts of the world and is a global problem. In many areas, arsenic levels in the environment have exceeded the safe threshold. Epidemiological studies have documented various adverse effects on the human population. Arsenic-contaminated soils, sediments, and sludge are the major sources of arsenic contamination 
of the food chain, surface water, groundwater, and drinking water (Frankenberger \& Arshad, 2002). Other potential sources of arsenic contamination are the chemicals used extensively in agriculture as pesticides, insecticides, defoliants, wood preservatives, and soil sterilants (Azcue \& Nriagu, 1994). Techniques currently available for the remediation of arsenic contaminated soils are expensive and time-consuming, often hazardous to workers, and capable of producing secondary wastes (Lombi et al., 2000). Phytoextraction, the use of green plants to clean up contaminated soil, has attracted attention as an environmentally- friendly, low-input remediation technique. It uses plants that extract heavy metals from the soil and accumulate it in the harvestable, above ground biomass (McGrath et al., 2002).

Several comprehensive reviews on phytoremediation and phytoextraction have been recently published (Salt et al., 1998; Robinson et al., 2003; Arthur et al., 2005; Ouyang, 2002). In the present review, phytoextraction of arsenic from contaminated soils by the recently discovered arsenic hyperaccumulator ferns, with emphasis on the recent studies developed in order to understand and enhance the arsenic removal process, will be discussed.

\section{ARSENIC}

Occurrence, availability and toxicity - Arsenic in the environment originates from both geochemical and anthropic sources. Arsenic concentration typically varies from below $10 \mathrm{mg} \mathrm{kg}^{-1}$ in non-contaminated soils (Adriano, 1986), to as high as $30,000 \mathrm{mg} \mathrm{kg}^{-1}$ in contaminated soils (Vaughan, 1993). In rocks, arsenic is concentrated in magmatic sulphide minerals and iron ores. The most important arsenic ores are arsenical pyrite or arsenopyrite (FeAsS), realgar (AsS), and orpiment $\left(\mathrm{As}_{2} \mathrm{~S}_{3}\right)$. Human activities have caused an accumulation of arsenic in soils mainly through the production or the use of arsenical pesticides (fungicides, herbicides, and insecticides). Due to manufacture of arsenic-based compounds, smelting of arsenic-containing ores, and combustion of fossil fuels, arsenic contamination can affect soils, water, and atmosphere (Azcue \& Nriagu, 1994), and has been identified as a major toxic contaminant in many countries. Industrialization has also lead to an increase in the amount of arsenic present in biosolids. Deposits from the atmosphere, runoff, and effluents of industries often increase the concentration of arsenic in biosolids. Woolson (1983) reported a range of 0 to $188 \mathrm{mg} \mathrm{kg}^{-1}$ As dry weight of biosolids. Biosolids are often disposed on land and may subsequently increase arsenic concentrations in the top $20 \mathrm{~cm}$ of soil by up to $0.15 \%$ (O’Neill, 1990).
Arsenic sorption on soil particles is one of the more important processes that immobilize this metalloid. Many studies have been devoted to arsenic sorption on well characterized minerals or soil particles (clay, oxides of Al, Fe, Mn, calcium carbonates and/ or organic matter) (Sadiq, 1997; Dobran \& Zagury, 2005). The high affinity of arsenic for oxide surfaces is well known and can be affected by several biogeochemical factors such as soil texture, organic matter content, nature and constituents of minerals, $\mathrm{pH}$, redox potential, and competing ions (Adriano, 2001). The activity of arsenic in soil solution is most commonly controlled by surface complexation reactions on oxides/hydroxides of $\mathrm{Al}, \mathrm{Mn}$, and especially $\mathrm{Fe}$ (Inskeep et al., 2002) which makes its availability highly dependent on soil attributes. For instance, the mobility of arsenic in soil is $\mathrm{pH}$ dependent, once arsenate is preferentially sorbed on hydrous oxides when $\mathrm{pH}$ values range from 4 to 7 , whereas, arsenite is preferentially sorbed when $\mathrm{pH}$ values range from 7 to 10 (Pierce \& Moore, 1982). Frost \& Griffin (1977) have also shown that arsenic sorption on kaolinite and montmorillonite is $\mathrm{pH}$ dependent, while Lin \& Puls (2000) confirmed that arsenate was more strongly sorbed than arsenite on these minerals. Furthermore, arsenate adsorption on humic substances was maximal for $\mathrm{pH}$ 5.5, while arsenite adsorption peaked at much higher $\mathrm{pH}$ of 8.5 (Thanabalasingam \& Pickering, 1986).

Bioavailability, toxicity, and chemical behavior of arsenic compounds are largely influenced by the form and speciation of arsenic. In natural systems, arsenic can exist essentially in four oxidation states: $(-3),(0),(+3)$, and $(+5)$. Arsenate $(\mathrm{As}(+5))$ and arsenite $(\mathrm{As}(+3))$ are the main forms present in soils (Harper \& Haswell, 1988). Arsenate prevails under aerobic conditions and is somewhat less toxic and also less mobile than arsenite (dominant form under anaerobic conditions) because arsenate sorbs more strongly than arsenite to minerals (Pierce \& Moore, 1982). Gaseous arsines are more toxic, whereas arsenobetaine and arsenocholine (mainly found in marine organisms) are nontoxic. As a rule, inorganic arsenicals are more toxic than organic arsenicals, while the trivalent oxidation state is more toxic than the pentavalent oxidation state (Adriano, 2001).

Remediation of arsenic contaminated soils - Many remediation techniques are available to address contamination problems in contaminated sites, but the relatively high capital expenditure, unsuitability for large areas, and environmental disruption are some of the shortcomings of those techniques, which vary in cost, intensity and timeframe. No single soil remediation technique is suitable for all situations. Careful inves- 
tigation of the contaminated site characteristics, contaminant problem, treatment options, and treatment timeframe must be considered.

Current remediation methods for arsenic-contaminated soils include soil removal and washing, physical stabilization, and/or the use of chemical amendments, all of which are expensive and disruptive, with an average cost of $\$ 404,700$ per ha (Raskin et al., 1997). Some selected current remediation technologies for arsenic-contaminated soil, adapted from USEPA (2002), follow:

a) Excavation - Commonly used ex-situ remediation method that involves the physical removal and disposal of contaminated soil in designated landfill. Even though it produces rapid remediation results, excavation is often expensive because of the operation, transport, and special landfill requirements (USEPA, 2002).

b) Capping - In-situ method. A hard cover is placed on the surface of the contaminated soil. Capping is also a rather simple method that reduces the contaminant exposure. However, it does not remove contaminants from the soil (USEPA, 2002).

c) Solidification and stabilization - In-situ method where the contaminated soil is mixed with stabilizers reducing the mobility of arsenic in soil. The drawbacks to these remediation techniques are that they can be relatively costly.

d) Vitrification - In-situ method where arsenic is chemically bonded inside a glass matrix forming silicoarsenates.

e) Soil washing/Acid extraction - Ex-situ treatment based on the suspension or dissolution of arsenic in a water-based wash solution to concentrate the contaminant.

f) Soil flushing: In-situ method that uses water, chemicals or organics to mobilize arsenic and flush it from the soil.

g) Phytoremediation/phytoextraction: In-situ method using plants to take up arsenic from soil.

\section{PHYTOREMEDIATION}

Phytoremediation includes any remediation method that utilizes plants to either remove pollutants or render them harmless in soil and water systems, and can be applied for both organic and inorganic pollutants present in soil, water, and air (Salt et al., 1998). This practice has been growing in popularity, because of its overall cost-effectiveness (Watanabe, 1997; Salt et al., 1998; Kabata-Pendias \& Pendias, 2001). The term phytoremediation includes several strategies: a) Phytoextraction - Phytoextraction is the use of pollutant-accumulating plants cap, able to extract and translocate pollutants to the harvestable parts. Phytoextraction is the most effective strategy of phytoremediation, although technically the most difficult. It uses tolerant plants that concentrate soil contaminants in their above ground biomass, so that the contaminant-enriched biomass can be properly disposed (Kramer, 2005).

b) Phytostabilization - Phytostabilization refers to the use of pollutant-tolerant plants for mechanical stabilization of polluted land in order to prevent bulk erosion, reduce air-borne transport, and leaching of pollutants. It is used to provide a cover of vegetation for a moderately to heavily contaminated site, thus preventing wind and water erosion (Kramer, 2005). Plants suitable for phytoestabilization develop extensive root system, provide good soil cover, possess tolerance to the contaminant metals, and ideally immobilize the contaminant in the rhizosphere. Arsenic-tolerant plants that may be potentially used for phytostabilisation purposes have been known for a long time (Rocovich \& West, 1975; Porter \& Peterson, 1977; Benson et al., 1981).

c) Phytoimmobilisation - Phytoimmoblization is the use of plants to decrease the mobility and bioavailability of pollutants by altering soil factors that lower pollutant mobility by formation of precipitates and insoluble compounds, as well as by sorption on roots. Based on the chemical similarities of arsenic and phosphorus, there may be precipitate formation of arsenic -/lead compounds as shown for phosphorus - lead precipitates in the rhizosphere of $A$. capillaris (CotterHowells et al., 1999). Other plant-mediated processes of arsenic immobilisation at the soil-root interface involve $\mathrm{pH}$ reduction and oxidation of the root environment by $\mathrm{O}_{2}$ released from roots. Doyle \& Otte (1997) found accumulation of arsenic on iron plaque in the oxidised rhizosphere of salt marsh plants that may provide effective immobilization and detoxification mechanism.

d) Phytovolatilization - Phytovolatilization is the use of plants to volatilize pollutants and has been demonstrated for $\mathrm{Hg}$ and Se. In case of $\mathrm{Hg}$, this was achieved by genetic manipulation of plants (Rugh et al., 1996), whereas, phytovolatilization of Se occurs naturally in plants (Terry \& Zayed, 1994). De Souza et al. (1999) demonstrated that rhizosphere bacteria can enhance Se volatilization and accumulation in plants. Volatilization of arsenic is also known to occur in natural environments (Frankenberger \& Arshad, 2002), but rhizosphere studies have not been reported for the forma- 
tion of gaseous arsenicals enhancement at the soil-root interface. Available information on arsenic volatilization for soil suggests that in the absence of plant roots, volatile compounds account only for small proportions of total arsenic (Turpeinen et al., 1999).

\section{PHYTOEXTRACTION OF ARSENIC}

Arsenic is a nonessential element for plants, and inorganic arsenic species are generally highly phytotoxic. Under normal conditions, arsenic concentrations in terrestrial plants are usually less than $10 \mathrm{mg} \mathrm{kg}^{-1}$ (Matschullat, 2000). Several plants contain arsenic in the following order: cabbage $\left(0.020-0.050 \mathrm{mg} \mathrm{kg}^{-1}\right)<$ carrots $(0.040-0.080)<$ grass $(0.020-0.160)<$ potatoes $(0.020-0.200)<$ lettuce $(0.020-0.250)<$ mosses and lichens (0.26) < ferns (1.3) (Matschullat, 2000).

An average toxicity threshold of $40 \mathrm{mg} \mathrm{kg}^{-1}$ was established for crop plants (Sheppard et al., 1992). Chemical behavior of arsenic is largely similar to that of phosphorus in soils. In all plant species tested so far, arsenate is taken up via the phosphate transport systems (Asher \& Reay, 1979; Lee, 1982; Meharg \& Macnair, 1992). Acting as a phosphate analog, arsenate can replace phosphate in many biochemical processes and disrupt phosphate metabolism in plants. For example, arsenate can disrupt mitochondrial oxidative phosphorylation and, thus, the production of the nucleotide adenosine triphosphate (ATP), which is a main energy source for cells. This process is known as arsenolysis, or the hydrolytic process whose first step is the replacement of arsenate by phosphate (Oremland \& Stolz, 2003). Unlike arsenate, arsenite reacts with sulfhydryl groups of enzymes and tissue proteins, leading to inhibition of cellular function and death (Meharg \& Hartley-Whitaker, 2002).

The transfer of arsenic from soil to plant is low for most plant species. This is probably due to: i) the restricted uptake by plant roots, ii) the limited translocation of arsenic from root to shoot, iii) arsenic phytotoxicity even at low concentrations in plant tissues, and iv) the low bioavailability of arsenic in soil (Wang et al., 2002).

Phytoextraction of arsenic from contaminated soils Phytoextraction is the most suitable for arsenic contaminated soils. It represents one of the largest economic opportunities for arsenic phytoremediation, due to the size and scope of environmental problems associated with contaminated soils, minimal environmental disturbance, public acceptance, and the competitive advantage offered by the plant-based remediation technology (Raskin et al., 1997; Susarla et al., 2002).

Following harvest of arsenic-enriched plants, the weight and volume of contaminated material can be further reduced, transported and disposed off site as hazardous material (Salt et al., 1998; Ma et al., 2001). Successful application of phytoextraction to arsenic contaminated soils depends on many factors, among which plant biomass and arsenic concentration are the most important. Plant species used to extract arsenic should be responsive to agricultural practices designed to enhance arsenic accumulation and to allow repeated planting and harvesting of arsenic-rich biomass (Tu \& Ma, 2002). However, continuous phytoextraction depends on the natural ability of a plant to accumulate, translocate and tolerate high concentrations of arsenic over the whole growth cycle (Garbisu \& Alkorta, 2001), as well as the arsenic bioavailability in the soil. Therefore, interactions of arsenic with soil matrix and the ability of plants to continually accumulate and detoxify metals in their shoot system are essential to the phytoremediation concept. Unfortunately, most metal-hyperaccumulator-plants grow quite slowly and have low biomass, while plants which quickly produce high biomass are usually sensitive to high metal concentrations. The energy costs of metal tolerance mechanisms are responsible for this phenomenon (trade-off hypothesis). There are, however, exceptions (e.g. the nickel hyperaccumulator Berkheya coddii and the arsenic hyperaccumulator ferns) that indicate that the capacity to accumulate and tolerate high metal concentrations in shoots and to produce high amounts of dry matter is not always mutually exclusive (Robinson et al., 1997; Ma et al., 2001).

Phytoextraction can be accomplished by using either tolerant, high-biomass plant species or hyperaccumulator plant species. Growth and remediation potential has been assessed for cottonwood (Populus deltoides Bartr.), cypress (Taxodium distichum L.), eucalyptus (Eucalyptus amplifolia Naudin, E. camaldulensis Dehnh., and E. grandis Hill), and leucaena (Leucaena leucocephala L.), which are all potential high-biomass species. However, the use of hyperaccumulator plants has the advantage of producing more concentrated residue, facilitating the final disposal of the contaminant-rich biomass.

\section{HYPERACCUMULATOR PLANTS}

Hyperaccumulators are plants that can take up and concentrate in excess of $0.1 \%$ of a given element in their tissue (Brooks, 1998). Metal hyperaccumulation is a rare phenomenon in terrestrial higher plants. To date, about 400 plant species have been identified as metal hyperaccumulators, representing $<0.2 \%$ of all angiosperms (Brooks, 1998; Baker et al., 2000). Approximately two-thirds of the known hyperaccumulators are Ni accumulators. This is because of the widespread occurrence of the Ni-rich ultramafic (serpentine) soils and the long history of geo- 
botanical studies of ultramafic floras. Plant species that are able to hyperaccumulate $\mathrm{Cd}, \mathrm{Co}, \mathrm{Cu}, \mathrm{Pb}, \mathrm{Zn}$, and As, are much less numerous.

The definition of metal hyperaccumulation has to take in consideration not only the metal concentration in the above ground biomass, but also the metal concentration in the soil. Both bioaccumulation factor (BF) and translocation factor (TF) have to be considered while evaluating whether a particular plant is a metal hyperaccumulator (Ma et al., 2001). The term $\mathrm{BF}$, defined as the ratio of metal concentration in plant biomass to that in the soil, has been used to determine the effectiveness of plants in removing metals from soil. The term TF, defined as the ratio of metal concentrations in plant shoot to those in the roots, has been used to determine the effectiveness of plants in translocating metals from the roots to the shoots (Tu \& Ma, 2002). Therefore, an arsenic hyperaccumulator plant should have $\mathrm{BF}>1$ and TF $>1$, as well as total accumulation $>1,000 \mathrm{mg} \mathrm{kg}^{-1}$ arsenic in plant biomass.

While some plants can survive in environments containing extremely high concentrations of metals, they may not show high ability of accumulating metals. For example, Agrostis tenuis concentrated 3,470 $\mathrm{mg} \mathrm{kg}{ }^{-1}$ of arsenic when grew in a soil containing as high as $26,500 \mathrm{mg} \mathrm{kg}^{-1}$ of arsenic. Even though the arsenic concentration in the plant was very high, it can not be characterized as arsenic hyperaccumulation, because the bioconcentration factor (BF) and translocation factor (TF) were lower than 1.

Arsenic hyperaccumulation in ferns - Hyperaccumulation of arsenic was discovered only recently, and the majority of plants that hyperaccumulate arsenic are fern species. First was Pteris vittata L. (Ma et al., 2001); followed Pityrogramma calomelanos L. (Francesconi et al., 2002) and many other species of the Pteris genus such as P. cretica L., P. longifolia L., P. umbrosa L., P. argyraea L. (Zhao et al., 2002), P. quadriaurita L., P. ryiunkensis L. and, P. biaurita (Srivastava et al., 2005).

Some other plants growing on mine wastes from various sites in the United Kingdom (Porter \& Peterson, 1977), and on smelter wastes in northeast Portugal (De Koe, 1994) have also been reported as arsenic hyperaccumulators $\left(>1,000 \mu \mathrm{g} \mathrm{g}^{-1}\right.$ As). However, though accumulating large amounts of arsenic, these plants do not concentrate arsenic, i.e. arsenic concentrations in the plant are lower than those in the soil. Ma et al. (2001) reported the first known arsenic hyperaccumulating plant, $P$. vittata, commonly known as Chinese Brake fern, which was found on a site contaminated with chromated copper arsenate wastes in Central Florida (Figure 1), with an average soil arsenic concentration of $361 \mathrm{mg} \mathrm{kg}^{-1}$, compared to background concentrations of $0.42 \mathrm{mg} \mathrm{kg}^{-1}$ in Florida soils (Chen et al., 1999).

Although there are a number of ferns known to accumulate arsenic, $P$. vittata is by far the most studied arsenic hyperaccumulator plant. It is native from China (Nelson, 2000) but is widespread in old-world, occurring from Europe to Asia. In the U.S., this fern grows in southeast and southern California (Ma et al., 2001). In Florida, P. vittata is one of the only three naturalized exotic ferns (Nelson, 2000). Pteris vittata ferns are very diverse and have survived in great numbers and adapted to both a vastly changing environment and competition from seed plants. They are widespread thriving in both temperate and tropical climates (Matschullat, 2000). Also, the distribution of $P$. vittata is controlled by its requirement of a well-drained, alkaline substrate exposed to abundant sunshine (Ma et al., 2001).

Pteris vittata has extraordinary capacity not only to tolerate and take up arsenic but also translocate large amounts of arsenic to the fronds, with shoot concentrations reaching levels $\sim 100$-fold greater than soil concentrations. In addition, this plant, with its high biomass, is an easy-to-grow, vigorous perennial, resistant to disease and pests, and that exhibits high arsenic accumulation rate. While natural arsenic concentrations in most plants seldom exceed $1 \mathrm{mg} \mathrm{kg}^{-1}$ (Porter \& Peterson, 1977), P. vittata accumulated 438-755 mg kg${ }^{1}$ As when grown in a uncontaminated soil, and 3,525 to $6,805 \mathrm{mg} \mathrm{kg}^{-1}$ As when grown in a contaminated soil for 6 weeks (Ma et al., 2001) (Figure 2). It also removed $26 \%$ of the added arsenate after 18 weeks of growth (Tu \& Ma, 2002). Liao et al. (2004) showed that, within seven months, $P$. vittata could extract up to $7.8 \%$ of the arsenic from soil where the arsenic concentration was $64 \mathrm{mg} \mathrm{kg}^{-1}$.

The ability of $P$. vittata to take up high concentrations of arsenic and sequester into aboveground

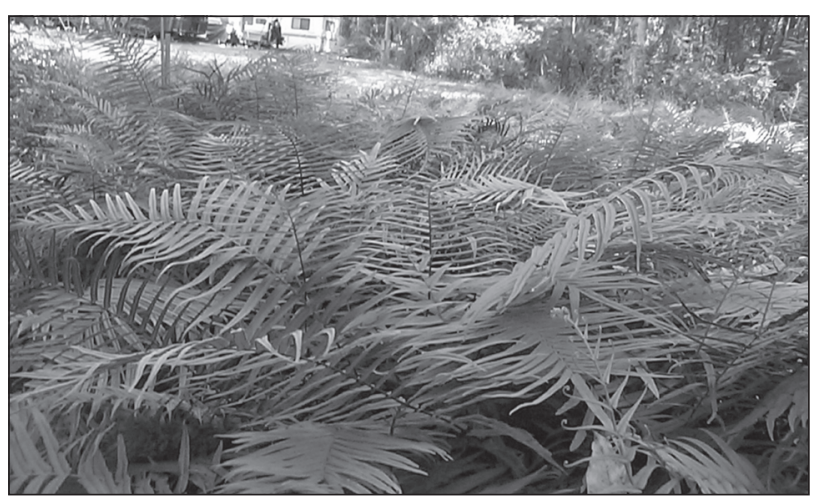

Figure 1 - Pteris vittata growing on a site contaminated with chromated copper arsenate wastes in Central Florida - USA. 
portions (Figure 3) when grown on either uncontaminated or arsenic-enriched soils implies that the fern has highly effective arsenic scavenging mechanisms. Differences in the amount of arsenic extracted from the soil by the plant are likely related to: i) the arsenic availability in the soil, ii) plant's growth period, and iii) weather or not the plants grew under greenhouse or field conditions. For instance, P. vittata cultivated under field conditions produced much more biomass from successive cuttings and accumulated more arsenic (Kertulius, 2005) than when the plants were cultivated in pot experiments under greenhouse conditions. Therefore, comparisons should be made with caution and taking in consideration all factors that influence biomass production and arsenic availability in soils. Another interesting characteristic of the ferns is their

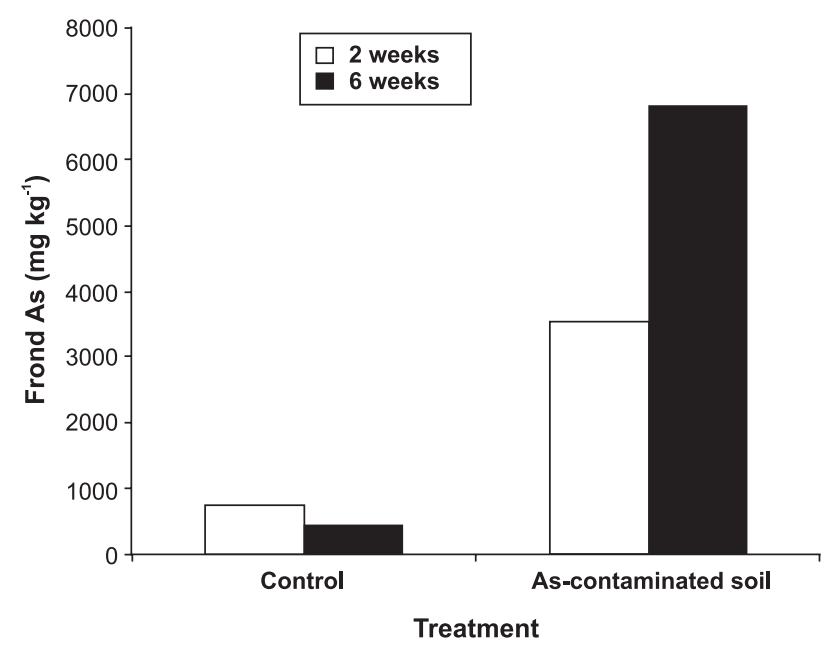

Figure 2 - Arsenic concentration in the fronds of Pteris vittata after growing for two and six weeks in uncontaminated soil (6 $\mathrm{mg} \mathrm{kg}^{-1}$ As) and Ascontaminated soil (400 $\left.\mathrm{mg} \mathrm{kg}^{-1} \mathrm{As}\right)$. Adapted from Ma et al., (2001).

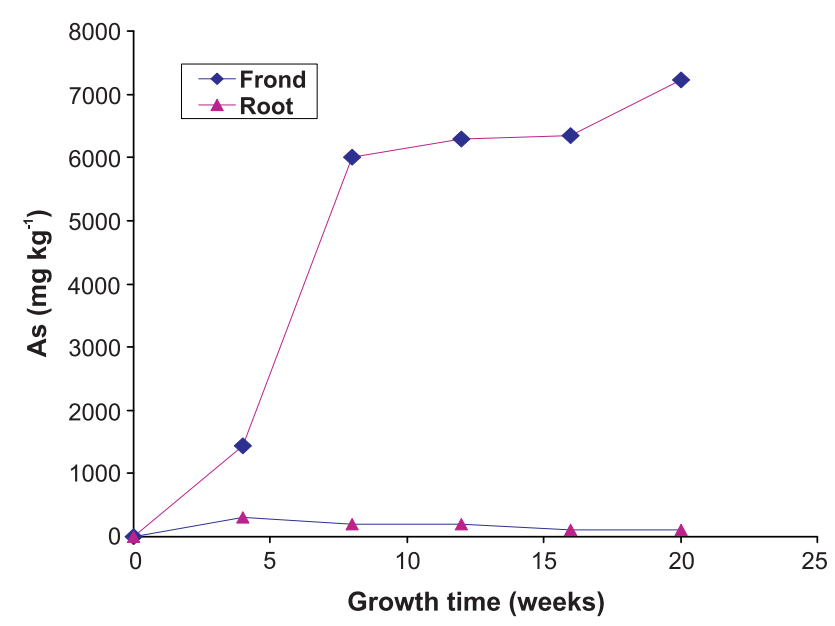

Figure 3 - Arsenic concentration in frond and roots of Pteris vittata after growing is As-contaminated soil (400 mg $\mathrm{kg}^{-1}$ ). Adapted from Ma et al., 2001. pereniality. The plants allow successive cuttings of the above ground biomass while growing in contaminated soils. Some results of pot experiments using $P$. vittata have shown that the amount of biomass harvested decreases after two or three successive cuttings as well as the amount of arsenic extracted from the soil (McGrath et al., 2002). However, Kertulis (2005) found opposite and positive results when grew $P$. vittata under field conditions.

Intriguing observations were made by Tu et al. (2002). In a pot experiment, they observed that the addition of $50 \mathrm{mg} \mathrm{kg}^{-1}$ arsenate to sandy soil increased the fern biomass by $107 \%$. After 12 weeks of growth, $P$. vittata produced more above ground biomass in soils containing 50 and $100 \mathrm{mg} \mathrm{kg}^{-1}$ arsenic in comparison to ferns grown in the soil not contaminated with arsenic. These results indicate that $P$. vittata may exhibit a need for arsenic to produce high biomass and extensive root growth, and that low levels of soil arsenic may actually be beneficial to the growth of this fern. However, when the soil arsenic concentration was 200 $\mathrm{mg} \mathrm{kg}{ }^{-1}$, there was a slight decrease in fern biomass. Another interesting fact is that arsenic has been shown to leach from $P$. vittata fronds as they senesce (Tu et al., 2003). This may pose a potential drawback to the use of $P$. vittata in phytoremediation of arsenic-contaminated soils, as the arsenic may be returned to the soil.

To date, the only non-Pteris fern to exhibit this ability is Pityrogramma calomelanos (Francesconi et al., 2002). Its fronds were able to accumulate 2,760 to $8,350 \mathrm{mg} \mathrm{kg}^{-1}$ As when grown in soil containing 135 to $510 \mathrm{mg} \mathrm{kg}^{-1}$ As. Interestingly, the fronds with the greatest arsenic concentration were collected from ferns growing in the lowest soil arsenic concentration (135 mg kg ${ }^{-1}$ As). Francesconi et al. (2002) stated that $P$. calomelanos readily removed arsenic from soils that were less contaminated. Therefore, these ferns have the ability to effectively reduce soil arsenic concentrations under these conditions.

Arsenic species in ferns - The form of arsenic hyperaccumulated by plants is important in determining its suitability to remediate arsenic contaminated sites, because the arsenic-rich fronds will need to be disposed properly to avoid further contamination (Ma et al., 2001). Pteris vittata has been shown to be capable of taking up both inorganic and organic arsenic species, including arsenate, arsenite, and monomethylarsonic acid (MMA) (Figure 4), concentrating up to $93 \%$ of the arsenic in the fronds (Ma et al., 2001; Kertulis et al., 2005). Their research on arsenic hyperaccumulation by $P$. vittata showed that arsenic exists in the plant mostly as inorganic species, 


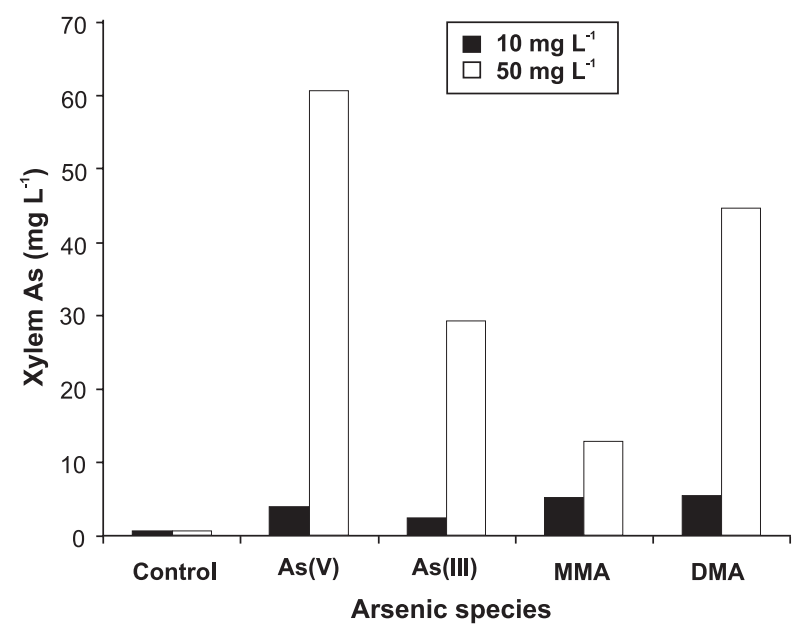

Figure 4 - Total arsenic concentration in Pteris vittata xylem sap of ferns exposed to 10 or $50 \mathrm{mg}$ L-1 As as As(V), As(III), MMA or DMA. Adapted from Kertulis et al. (2005).

and up to $94 \%$ of the arsenic in the fronds is present as arsenite. Similar results were observed when arsenic was supplied to ferns in several different forms (Zhang et al., 2002; Tu et al., 2003; Kertulis et al., 2005). Regardless of the arsenic species supplied to the fern, $>90 \%$ of the total arsenic in the roots is present as arsenate, versus approximately $94 \%$ arsenite in the fronds. In both studies, very low concentrations of organic arsenic were found in the fern. Similarly, in a study involving $P$. calomelanos, most of the arsenic found in its fronds was arsenite. Only trace amounts of MMA and DMA were found in a few samples (Francesconi et al., 2002).

The uptake of arsenite and arsenate by $P$. vittata roots may not be equal, because the species may be taken up through different mechanisms in the roots. For instance, Wang et al. (2002) found that arsenate was taken up more quickly by $P$. vittata than was arsenite, especially in the absence of phosphate. The authors suggest that this is due to arsenate being assimilated via phosphorus-suppressible uptake in the roots. Meharg \& Jardine (2003) suggest that aquaglyceroporins are the main inlet for arsenite into rice. Therefore, the root uptake rates of arsenite and arsenate into the plant roots may be different.

Arsenic tolerance and detoxification mechanisms Plants often contain trace concentrations of many contaminants of concern. At low levels, plants can usually metabolize or dispose off these compounds without any significant injury. Generally, at high contaminant concentrations in soil or water, plants are not able to metabolize these harmful elements. However, some plants can survive and even grow well when they accumulate high concentrations of toxic elements, as is the case of the hyperaccumulator plants. In ferns like $P$. vittata, arsenic is taken up at high rates and at concentration proportional to the arsenic concentrations in the growth media (Ma et al., 2001; Zhang et al., 2002; Wang et al., 2002; Kertulis et al., 2005), at least up to a certain point where arsenic availability becomes a limiting factor and the plant arsenic concentration exceeds the detoxification ability of the plants.

The fact that Pteris vittata could survive in soil contaminated with $1,500 \mathrm{mg} \mathrm{kg}^{-1}$ arsenic and concentrate $2.3 \%$ of arsenic in its biomass, indicates that these hyperaccumulating ferns possess efficient mechanisms for detoxifying accumulated arsenic. These mechanisms are believed to include chelation, compartmentalization, biotransformation and cellular repair (Salt et al., 1998). For example, heavy metals are generally transported and deposited in a vacuole as metal chelates. Baker et al. (2000) reported that the solution concentration of free metal ions taken up by plants into their tissues is reduced greatly when they are chelated by specific, high-affinity ligands (such as oxygen-donor, sulfur-donor, or nitrogen-donor ligands). Sulfur-donor ligands (luch as metallothioneins and phytochelatins) form highly stable complexes with heavy metals, because sulfur is a better electron donor than oxygen. In fact, the reduction of arsenate to arsenite is catalyzed by glutathione (GSH) in microbes (Rosen, 2002). However, this has not been demonstrated in $P$. vittata

The formation of arsenite-tris-thiolate complexes has been demonstrated both in vivo and in vitro, by electrospray ionization mass spectroscopy (Schmoger et al., 2000) and x-ray absorption spectroscopy (Pickering et al., 2000), with the thiolate derived from either GSH or phytochelatins (PCs). Most reports on arsenic toxicity in plants show a clear role for PCs in the detoxification of arsenic with these compounds (Schmoger et al., 2000; Hartley-Whitaker et al., 2001, 2002; Schat et al., 2002). Reina et al. (2005) demonstrated that PCs were the most abundant thiols in white lupin under higher arsenic exposure levels than other plants could tolerate. Together, GSH and PCs were able to complex the majority of arsenic in shoots. However, the role of PCs seems to be minor in the arsenic hyperaccumulator ferns (Zhao et al., 2003; Raab et al., 2004; Zhang et al., 2004).

As for the other hyperacumulator plants, the reduction of arsenate to arsenite inside plant cells in the arsenic hyperaccumulator $P$. vittata (Ma et al., 2001) and P. calomelanos (Pickering et al., 2000) occurs as well. This reduction of arsenate inside the plant cells is an intriguing process because arsenite is more toxic than arsenate. Additionally, $P$. vittata was shown to have only $4.5 \%$ of its arsenic complexed with phytochelatins, as a glutathione-arsenite-phytochelatin 
complex (Zhao et al., 2003). In a study by Raab et al. (2004), the arsenic hyperaccumulator, P. cretica, had only $1 \%$ of its arsenic complexed with phytochelatins. The conclusion reached in both studies was that the phytochelatins may act as shuttles the arsenic transport in a non-toxic form through the cytoplasm and into the vacuoles. However, the arsenic complexation with phytochelatins by itself does not account for the highly efficient detoxification mechanism in arsenic hyperaccumulating ferns, suggesting a novel mechanism of arsenic tolerance in $P$. vittata.

Arsenic detoxification might also include methylation and biotransformation by microorganisms. Some bacteria enzymatically reduce arsenate to arsenite by Ars $\mathrm{C}$, and the arsenite is then pumped out by the membrane protein Ars B (Cai \& Ma, 2003). None of these mechanisms were identified in the ferns. Therefore, an important gap in the arsenic hyperaccumulation mechanism is how the ferns rapidly translocate arsenite from the root to the shoot, and are still able to survive the exceedingly high concentrations of frond arsenite that perturbs the cellular function by disrupting the sulfhydryl groups of proteins. Although there is already exhaustive research and a vast knowledge in the field of phytoremediation, the uncovering of the detoxification mechanisms of hyperacumulator ferns could lead phytoremediation technology to a new level.

Effect of heavy metals on arsenic hyperaccumulation by ferns - Some contaminated sites contain a variety of contaminants. So another important point to be considered is the ability of arsenic hyperaccumulator plants to grow in soil contaminated with other heavy metals. The ability of $P$. vittata to survive and thrive in soil contaminated with $\mathrm{Cu}$ and $\mathrm{Cr}$ is confirmed by the fact that this fern was first discovered in a CCA (chromated-copper-arsenate) contaminated soil. The total arsenic in that soil was $131 \mathrm{mg} \mathrm{kg}^{-1}$, $\mathrm{Cr}$ was $40.6 \mathrm{mg} \mathrm{kg}^{-1}$, and Cu was $8.30 \mathrm{mg} \mathrm{kg}^{-1}$. Fayiga et al. (2004) studied the effects of doses of $\mathrm{Cd}, \mathrm{Ni}, \mathrm{Pb}$, and $\mathrm{Zn}$ on the arsenic accumulation by $P$. vittata and observed that concentrations of heavy metal that would negatively affect the growth of normal, non-accumulating plants did not have the same impact on the fern. Total plant biomass was up to 12 times greater when grown in metal-spiked soils, with the exception of the Ni treatments, than those of the control. The total biomass of the treatments were in order of Cd-50 > Pb-200 > Zn-200 > Pb-50 > Cd-200 > Zn$50>$ control $>\mathrm{Ni}-50>\mathrm{Ni}-200$, with Cd-50 and Pb-200 being higher than other treatments. However, the efficiency of arsenic accumulation by the fern depended on the concentration of other metals in the soil (Fayiga et al., 2004; An et al., 2005).
In the study of Fayiga et al. (2004), arsenic uptake decreased with increasing metal concentration for each metal, except in lead-treated soils. Though effective in taking up arsenic, $P$. vittata had limited capability to take up other metals. Arsenic transfer factors ranging from 15.8 to 46.1 indicate that $P$. vittata effectively translocated arsenic in the presence of other metals. Caille et al. (2004) reported that $P$. vittata grew poorly in a soil heavily contaminated with $\mathrm{As}, \mathrm{Cu}, \mathrm{Pb}$, and $\mathrm{Zn}$, probably as a result of $\mathrm{Zn}$ and $\mathrm{Cu}$ toxicity. The concentrations of $\mathrm{Zn}$ and $\mathrm{Cu}$ in the plants were well above the toxicity thresholds of $100-500 \mathrm{mg} \mathrm{kg}^{-1} \mathrm{Zn}$ and $20 \mathrm{mg} \mathrm{kg}^{-1} \mathrm{Cu}$, respectively, reported for a wide range of plant species (Kabata-Pendias \& Pendias, 2001). Phytotoxicity of $\mathrm{Zn}$ and $\mathrm{Cu}$ not only decreased plant growth, but also arsenic uptake, resulting in a negligible phytoextraction of As from the soil. Contamination by multiple metals or metalloids, particularly at high concentrations, thus presents a difficult challenge for phytoremediation.

Effect of phosphate on arsenic hyperaccumulation by ferns - Competitive effect of arsenate and phosphate in soils has been demonstrated (Livesey \& Huang, 1981; Manning \& Goldberg, 1997; Smith et al., 2002; Tu \& Ma, 2003), as well as the interactions of these two elements in plants (Asher \& Reay, 1979; Meharg \& Macnair, 1992; Fourqurean \& Cai, 2001). Basically, the uptake of arsenate and phosphate by plants has been reported to be competitive (Tu \& Ma, 2003). Moreover, arsenate interferes with phosphate metabolism causing toxicity to plants. On the other hand, phosphate may be able to alleviate arsenate toxicity by improving phosphate nutrition (Sneller et al., 1999). Thus, the presence of phosphorus in contaminated soils plays a role in the phytoextraction process.

Tu \& Ma (2003) studied the influence of phosphate on the arsenic phytoextraction by $P$. vittata and reported that, at low and medium arsenate levels (50 $\mathrm{mg} \mathrm{kg}^{-1}$ and $200 \mathrm{mg} \mathrm{kg}^{-1}$, respectively), phosphate had little effect on arsenate accumulation by and growth of $P$. vittata. However, phosphate substantially increased plant biomass and arsenate accumulation by alleviating arsenate phytotoxicity at high arsenate levels (400 $\mathrm{mg} \mathrm{kg}^{-1}$ ). The authors suggested a minimum $\mathrm{P} /$ As molar ratio of 1:2 in soil solution to the effective removal of arsenic by the plant.

Fayiga \& Ma (2005) reported that addition of phosphate rock in a soil spiked with arsenic and other metals increased plant arsenic uptake, increasing from 608 to $1,046 \mathrm{mg} \mathrm{kg}^{-1}$ in the fronds. This shows the ability of phosphate rock to aid in arsenic accumulation by P.vittata in a multi-metal system by reducing the toxic effects of the metals on the fern; thereby, enhanc- 
ing the arsenic uptake. Boisson et al. (1999) also reported an increase in arsenic uptake by plants (Zea mays cv. Volga and Phaseolus vulgaris cv. Limburgse vroege) after applying hydroxyapatite to a soil contaminated with $\mathrm{Zn}, \mathrm{Pb}, \mathrm{Cu}, \mathrm{Cd}$, and As. They suggested that the increased phosphate concentration in the soil solution might be responsible, since phosphate can displace adsorbed arsenate from soils and increase the solubility of arsenate (Smith \& Naidu, 1998).

In a chromated-copper-arsenate contaminated sandy soil, addition of a large amount of rock phosphate $\left(15 \mathrm{~g} \mathrm{~kg}^{-1}\right)$ also increased arsenate uptake by $P$. vittata (Cao et al., 2003). Therefore, phosphorus additions, in the first place, enhanced plant growth, and secondly, mobilized exchangeable arsenic resulting in increased total arsenic uptake. One should consider that a large proportion of phosphorus in soil is in organic form such as phytates (Marschner, 2003) and are expected to compete with arsenic for sorption sites.

Despite the appeal of increased arsenic availability from application of soil amendments such as phosphorus fertilizers for the purpose of phytoremediation, it is environmentally paradoxical in that the benefit of enhanced arsenic removal from soils may be offset by the risk of increased arsenic leaching into ground water. Therefore, the rate of arsenic uptake should be higher than the rate of arsenic release in the soil. In this regard, a very extensive root system is a valuable characteristic in a hyperaccumulator plant. Gonzaga et al (2006; data not yet published) ${ }^{1}$ compared $P$. vittata root system with a non arsenic accumulator fern Nephrolepis exaltata, and registered much larger and extensive fine roots for $P$. vittata. Tu et al. (2002) found similar results.

Mycorrhizae association with ferns and role on arsenic hyperaccumulation - Mycorrhizae have a welldocumented role in increasing plant uptake of phosphorus (Smith \& Read, 1997) and other poorly mobile elements, and are recognized as important components of bioremediation strategies for heavy metals (Khan et al., 2000). In fact, mycorrhizi are integral, functional components of plant root systems and the fungi involved can play an important role either in alleviating metal toxicity in plants or enhancing metal uptake. For instance, Weissenhorn \& Leyval (1995) reported higher concentrations of heavy metals in plants due to arbuscular mycorrhizae colonization, even resulting in toxic levels in plants, while Heggo et al. (1990) observed reduced metal concentrations in plants (or in shoots) due to mycorrhizal colonization. On the other hand, Galli et al. (1995) found no effects exerted by arbuscular mycorrhizae fungi on metal concentrations in shoots and roots.

Since arsenic and phosphorus are chemical analogues, it is reasonable to expect that mycorrhizal symbiosis may be involved in As uptake as well as $\mathrm{P}$ uptake by the arsenic hyperaccumulator plants. However, few studies have been done in this regard. Ying et al. (2004) investigated the colonization and diversity of arbuscular mycorrhizae fungi associated with common pteridophytes and found no defined relationship between mycorrhizas and plants under field condition. Out of all recent reported arsenic hyperaccumulator ferns, only $P$. vittata association with mycorrhizae has well been investigated so far (Al Agely et al., 2005; Leung et al., 2006).

Al Agely et al. (2005) studied the effect of increasing levels of arsenic and phosphorus on $P$. vittata infected with mycorrhizae and observed that the arbuscular mycorrhizae fungi not only tolerated arsenic amendment, but its presence increased frond dry mass at the highest arsenic application rate $\left(100 \mathrm{mg} \mathrm{kg}^{-1}\right)$. The arbuscular mycorrhizae fungi also increased arsenic uptake across a range of phosphorus levels, while phosphorus uptake was generally increased only when there was no arsenic amendment, suggesting an important role of arbuscular mycorrhizae fungi in arsenic accumulation by $P$. vittata.

The percentage of mycorrhizal infection in $P$. vittata increased as soil arsenic concentrations increased (Leung et al., 2006). The authors also reported an increase in arsenic accumulation by $P$. vittata infected with mycorrhizae and improvement of the nutrient status of the plants. The presence of mycorrhizae likely increased the amount of $\mathrm{P}$ transporters at hyphae level and, consequently, the amount of arsenic taken up by the plant, considering the similar behavior of arsenic and phosphorus and the competition for uptake. The presence of mycorrhizae also seems to be related to the formation of thiol like glutathione (Schutzendubel \& Andrea, 2002), a phenolic defense system. It is hypothesized that the production of thiols by $P$. vittata, induced by the increased arsenic concentration, alleviates the toxicity of arsenic (Cai et al., 2004) and the plant can readily retain arsenic with the aid of mycorrhizas (Diaz et al., 1996). Therefore, it is possible that $P$. vittata may derive some benefit from the symbiosis by forming low molecular weight thiols. More research is needed to investigate the role of rhizosphere microorganisms on the arsenic removal from contaminated soils.

M.I.S. Gonzaga, Soil and Water Science Department, University of Florida - PO Box 110510 - Gainesville, FL - USA - 32611-0290. e-mail<isis@ufba.br>. 


\section{CONCLUDING REMARKS}

Phytoextraction is a fairly new technology and is very dependent on plant and soil factors, such as soil suitability for plant growth, depth of the contamination, depth of the plant root system, level of contamination, and urgency in cleaning up. Furthermore, there is need for a full understanding of the physiology, biochemistry, uptake, etc., of the plants employed.

A relatively small group of plants are capable of sequestering arsenic in their shoot tissues at high concentrations with the majority of them belonging to the Pteridophytes, which are lower plants. This group of plants offers the challenge of efficient reproduction for large scale phytoremediation. Cultivation of arsenic hyperaccumulators has to be optimized in order to provide an effective alternative to common engineeringbased remediation technologies. In recent years, major scientific progress has been made in understanding the physiological mechanisms of arsenic uptake and transport in these plants. However, very little is known about the molecular basis of hyperaccumulation. Therefore, the future research should focus on the molecular-genetic technologies and, possibly, transgenic plants with increased resistance and uptake not only of arsenic but also other heavy metals. Discovering the molecular mechanisms underlying arsenic tolerance and accumulation in the arsenic hyperaccumulator ferns can be facilitated by identifying genes that are both necessary and sufficient for these properties.

Although phytoextraction is a promising remediation technology, it is in its early stage of development and very little information is available related to site clean up from start to finish. This is probably due to the fact that few, if any, sites that have yet to be completely remediated. This is quite true for the case of arsenic phytoextration. The first arsenic hyperaccumulator plant was only discovered in 2001 by $\mathrm{Ma}$ and co-workers. It is estimated that 10 to 14 years would be needed to completely remediate the top $15 \mathrm{~cm}$ of soil using P.vittata to meet the residential site and/or commercial site Florida DEP requirements, 2.1 and $9.3 \mathrm{mg} \mathrm{kg}^{-1}$ As.

\section{REREFENCES}

ADRIANO, D.C. Trace elements in the terrestrial environment. New York: Springer, 1986. 867p.

ADRIANO, D.C. Trace Elements in the Terrestrial Environment. New York: Springer, 2001. 867p.

AL AGELY, A.; SYLVIA, D. M.; MA, L. Q. Mycorrhizae increase arsenic uptake by the hyperaccumulator chinese brake fern (Pteris vittata L.). Journal of Environmental Quality, v.34, p.2181-218, 2005.
AN, Z.Z.; HUANG, Z.C.; LEI, M.; LIAO, X.Y.; ZHENG,Y.M.; CHEN, T.B. Zinc tolerance and accumulation in Pteris vittata L. and its potential for Phytoremediation of $\mathrm{Zn}$ - and As-contaminated soil. Chemosphere, 2005. Disponível em: <http://www.sciencedirect. com/science>. Acesso em: 28 de junho de 2005

ARTHUR, E.L.; RICE, P.J.; RICE, P.J.; ANDERSON, T.A.; BALADI, S.M. Phytoremediation: an overview. Critical Reviews in Plant Sciences, v.24, p.109-122, 2005.

ASHER, C.J.; REAY, P.F. Arsenic uptake by barley hordeum-vulgare cultivar zephyr seedlings. Australian Journal of Plant Physiology, v.6, p.459-/466, 1979.

AZCUE, J..M.; NRIAGU, J.O. Arsenic: historical perspectives. In: NRIAGU, J.O (Ed.). Arsenic in the environment. New York: Jonh Wiley and Sons, 1994. p.1-15

BAKER, A.J.M.; MCGRATH, S.P.; REEVES, R.D.; SMITH, J.A.C. Metal hyperaccumulator plants: a review of the ecology and physiology of a biochemical resource for phytoremediation of metalpolluted soils. In: TERRY, N.; BAÑUELOS, G. (Ed.) Phytoremediation of contaminated soil and water. Boca Raton: Lewis Publishers, 2000. p.85-107.

BENSON, L.M.; PORTER, E.K.; PETERSON, P.J. Arsenic accumulation, tolerance, and genotypic variation in plants on arsenical mine wastes in S.W. England. Journal of Plant Nutrition, v.3, p.655-666, 1981.

BOISSON, J.; MENCH, M.; VANGRONSVELD, J.; KOPPONEN, P.; DE KOE, T. Immobilization of trace metals and arsenic by different soil additives: evaluation by means of chemical extractions. Communications in Soil Science and Plant Analysis, v.30, p.365-387, 1999.

BROOKS, R.R. Plants that hyperaccumulate heavy metals. Cambridge: University Press, 1998. 380p.

CAI, Y.; MA, L. Metal tolerance, accumulation, and detoxification in plants with emphasis on arsenic in terrestrial plants. In: CAI, Y.; BRAIDS, O.C. (ED.) Biogeochemistry of Environmentally Important Trace Elements. Washington, DC: Oxford University Press, 2003.436p.

CAI, Y.; SU, J.H.; MA, L.Q. Low molecular weight thiols in arsenic hyperaccumulator Pteris vittata upon exposure to arsenic and other trace elements. Environmental Pollution, v.129, p.69-78, 2004.

CAILLE, S.; SWANWICK, S.; ZHAO, F.J.; MCGRATH, S.P. Arsenic hyperaccumulation by Pteris vittata from arsenic contaminated soils and the effect of liming and phosphate fertilization. Environmental Pollution, v.132, p.113-120, 2004.

CAO, X.; MA, L.Q.; SHIRALIPOUR, A. Effects of compost and phosphate amendments on arsenic mobility in soils and arsenic uptake by the hyperaccumulator Pteris vittata L. Environmental Pollution, v.126, p.157-167, 2003.

CHEN, M.; MA, L.Q.; HARRIS, W.G. Baseline concentrations of 15 trace metals in Florida surface soils. Journal of Environmental Quality, v.28, p.1173-1181, 1999.

COTTER-HOWELLS, J.D.; CHAMPNESS, P.E.; CHARNOCK, J.M. Mineralogy of $\mathrm{Pb}-/ \mathrm{P}$ grains in the roots of Agrostis capillaris L. by ATEM and EXAFS. Mineralogy Magazine, v.63, p.777-789, 1999.

DE KOE, T. Agrostis castellana and Agrostis delicatula on heavy metal and arsenic enriched sites in NE Portugal. Science of the Total Environment, v.145, p.103-109, 1994.

DE SOUZA, M.P.; CHU, D.; ZHAO, M.; ZAYED, A.M.; RUZIN, S.E.; SCHICHNESS, D.; TERRY, N. Rhizosphere bacteria enhance selenium accumulation and volatilisation by Indian mustard. Plant Physiology, v.119, p.563-573, 1999.

DIAZ, G.; AZCON-AGUILAR, C.; HONRUBIA, M. Influence of arbuscular mycorrhizae on heavy metal $(\mathrm{Zn}$ and $\mathrm{Pb})$ uptake and growth of Legeum spartum and Anthyllis cytisoides. Plant and Soil, v.180, p.241-249, 1996.

DOBRAN, S.; ZAGURY, G. Arsenic speciation and mobilization in CCA-contaminated soils: Influence of organic matter content. The Science of the Total Environment, 2005. Disponível em: <http:// www.sciencedirect.com/science>. Acesso em: 1 de agosto de 2005

DOYLE, M.O.; OTTE, M.L. Organism-induced accumulation of iron, zinc and arsenic in wetland soil. Evironmental Pollution, v.96, p.1-/11, 1997. 
FAYIGA, A. O.; MA, L.Q.; CAO, R. X.; RATHINASABAPATHI, D. B. Effects of $\mathrm{Cd}, \mathrm{Ni}, \mathrm{Zn}$, and $\mathrm{Pb}$ on plant growth and arsenic uptake of hyperaccumulator Pteris vittatain a contaminated soil. Environment Pollution, v. 132, p.289-296, 2004.

FAYIGA, A.O.; MA, L.Q. Using phosphate rock to immobilize metals in soil and increase arsenic uptake by hyperaccumulator Pteris vittata . Science of the Total Environment, 2005. Disponível em: $<$ http://www.sciencedirect.com/science>. Acesso em: 27 de junho de 2005

FOURQUREAN, J.W.; CAI, Y. Arsenic and phosphorus in seagrass leaves from the Gulf of Mexico. Aquatic Botany, v.71, p.247-258, 2001.

FRANCESCONI, K.; VISOOTTIVISETH, P.; SRIDOKCHAN, W.; GOESSLER, W. Arsenic species in an arsenic hyperaccumulatingfern, Pityrogramma calomelanos: a potential phytoremediator of arsenic-contaminated soils. Science of the Total Environment, v.284, p27-35, 2002.

FRANKENBERGER, W.T.J.R.; ARSHAD, M. Volatilisation of arsenic. In: FRANKENBERGER JR., W.T. (Ed.). Environmental chemistry of arsenic. New York: Marcel Dekker, 2002. p.363-/380.

FROST, R.R.; GRIFFIN, R.A. Effect of $\mathrm{pH}$ on adsorption of arsenic and selenium from landfill leachate by clay minerals. Soil Science Society of America Journal, v.41, p.53-57, 1977.

GARBISU, C.; ALKORTA, I. Phytoextraction: a cost-effective plantbased technology for the removal of metals from the environment. Bioresource and Technology, v.77, p.229-236, 2001.

GALLI, U.; SCHUEPP, H.; BRUNOLD, C. Thiols of Cu-treated maize plants inoculated with the arbuscular-mycorrhizal fungus Glomus intraradices. Physiology Plantarum, v.94, p.247-253, 1995.

HARPER, M.; HASWELL, S.J. A comparison of copper, lead and arsenic extraction from polluted and unpolluted soils. Environmental Technology Letters, v.9, p.1271-1280, 1988.

HARTLEY-WHITAKER, J.; AINSWORTH, G.; VOOIJS, R.; TEN BOOKUM, W.; SCHAT, H.; MEHARG, A.A. Phytochelatins are involved in differential arsenate tolerance in Holcus lanatus. Plant Physiology, v.126, p.299-306, 2001.

HARTLEY-WHITAKER, J.; WOODS, C.; MEHARG, A.A. Is differential phytochelatin production to decreased arsenate influx in arsenate tolerant Holcus lanatus? New Phytologist, v.155, p.219225, 2002.

HEGGO, A.; ANGLE, A.; CHANEY, R.L. Effects of vesicular arbuscular mycorrhizal fungi on heavy metal uptake by soybeans. Soil Biology and Biochemistry, v.22, p.865-869, 1990.

INSKEEP, W.P.; MCDERMOTT, T.R.; FENDORF, S. Arsenic (V)/(III) cycling in soil and natural waters: chemical and microbiological processes. In: FRANKENBERGER JR., W.T. (Ed.). Environmental chemistry of arsenic. New York: Marcel Dekker, 2002. p.183-/215.

KABATA-PENDIAS, A.; PENDIAS, $\mathrm{H}$. Trace elements in soils and plants. Boca Raton: CRC Press, 2001. 413p.

KERTULIS, G.M.; MA, L.Q.; MACDONALD, G.E.; CHEN, R.; WINEFORDNER, J.D.; CAI, Y. Arsenic speciation and transport in Pteris vittata L. and the effects on phosphorus in the xylem sap. Environmental and Experimental Botany, v.54, p.239-247, 2005.

KERTULIS, G.M. Arsenic hyperaccumulation by Pteris vittata L and its potential for phytoremediation of arsenic-contaminated soils. Gainesville: University of Florida., 2005. 156p. Thesis (Ph.D.).

KHAN, A.G.; KUEK, C.; CHAUDHRY, T.M.; KHOO, C.S.; HAYES, W.J. Role of plants, mycorrhizae and phytochelators in heavy metal contaminated land remediation. Chemosphere, v.41, p.197-207, 2000.

KRAMER, U. Phytoremediation: novel approaches to cleaning up polluted soils. Current Opinion in Biotechnology, v.16, p.133-141, 2005.

LEE, R.B. Selectivity and kinetics of ion uptake by barley plants following nutrient deficiency. Annals of Botany, v.50, p.429-449, 982.

LEUNG, H.M.; YE, Z.H.; WONG, M.H. Interactions of mycorrhizal fungi with Pteris vittata (As hyperaccumulator) in As-contaminated soils. Environmental Pollution, v.139, p.1-8, 2006.
LIAO, X.Y.; CHEN, T.B.; LEI; M.; HUANG, Z.C.; XIAO, X.Y.; AN, Z.Z. Root distribution and elemental accumulations of Chinese brake (Pteris vittata L) from As-contaminated soils. Plant and Soil, v.261, p.109-116, 2004.

LIN, Z.; PULS, R.W. Adsorption, desorption, and oxidation of arsenic affected by clay minerals and aging process. Environmental Geology, v.39, p.753-759, 2000.

LIVESEY, N.T.; HUANG, P.M. Adsorption of arsenate by soils and its relation to selected chemical properties and anions. Soil Science, v.134, p.88-94, 1981.

LOMBI, E.; ZHAO, F.J.; DUNHAM, S.J.; MCGRATH, S.P. Cadmium accumulation in populations of Thlaspi caerulenses and Thlaspi goesingense. New Phytologist, v.145, p.11-20, 2000.

MA, L.Q.; KOMAR, K.M.; TU, C.; ZHANG, W.; CAI, Y.; KENNELLEY, E.D. A fern that hyperaccumulates arsenic. Nature, v.409, p.579, 2001.

MANNING, B.A.; GOLDBERG, S. Arsenic(III) and arsenic(V) adsorption on three California soils. Soil Science, v.162, p.886-895, 1997.

MARSCHNER, H. Mineral nutrition of higher plants. New York: Academic Press, 2003. 889p.

MATSCHULLAT, J. Arsenic in the geosphere-a review. Science of the Total Environment, v.249, p.297-312, 2000.

MCGRATH, S.P.; ZHAO, F.J.; LOMBI, E. Phytoremediation of metals, metalloids, and radionuclides. Advances in Agronomy, v.75, p.156, 2002.

MEHARG, A. A.; MACNAIR, M.R. Suppression of the high-affinity phosphate uptake system: a mechanism of arsenate tolerance in Holcus lanatus L. Journal of Experimental Botany, v.43, p.519524, 1992.

MEHARG, A.A.; HARTLEY-WHITAKER, J. Arsenic uptake and metabolism in arsenic-resistant and nonresistant plant species. New Phytologist, v.154, p.29-43, 2002.

MEHARG, A.A.; JARDINE, L. Arsenite transport into paddy rice (Oryza sativa) roots. New Phytologist, v.157, p.39-44, 2003.

NELSON, G. The ferns of Florida: a reference and field guide. Sarasota: Pineapple Press, 2000. 200p.

O’NEIL, P. Arsenic. In: ALLOWAY, B.J. (Ed.). Heavy metals in soils. New York: John Wiley and Sons, 1990. p.83-99.

OREMLAND, R.S.; STOLZ, J.F. The ecology of arsenic. Science, v.300, p.939-944, 2003.

OUYANG, Y. Phytoremediation: modeling plant uptake and contaminant transport in the soil-plant-atmosphere continuum. Journal of Hydrology, v.266, p.66-82, 2002.

PICKERING, I.J.; PRINCE, R.C.; GEORGE, M.J.; SMITH, R.D.; GEORGE, G.N.; SALT, D.E. Reduction and coordination of arsenic in Indian mustard. Plant Physiology, v.122, p.1171-1177, 2000.

PIERCE, M.L.; MOORE, C.B.; Adsorption of arsenite and arsenate on amorphous iron hydroxide. Water Residue, v.16, p.1247-1253, 1982.

PORTER, E.K.; PETERSON, P.J. Arsenic tolerance in grasses growing on mine waste. Environmental Pollution, v.14, p.255-265, 1977.

RAAB, A.; FELDMANN, J.; MEHARG, A.A. The nature of arsenicphytocheltin complexes in Holcus lanatus and Pteris cretica. Plant Physiology, v.134, p.1113-1122, 2004.

RASKIN, I.; SMITH, R.D.; SALT, D.E. Phytoremediation of metals: using plans to remove pollutants from the environment. Current Opinion on Biotechnology, v.8, p.221-226, 1997.

REINA, S.V.; ESTEBAN, E.; GOLDSBROUGH, P. Arsenate-induced phytochelatins in white lupin: influence of phosphate status. Physiology Plantarum, v.124, p.41, 2005.

ROBINSON, B.H.; BROOKS, R.R.; HOWES, A.W., KIRKMAN, J.H.; GREGG, P.E.H. The potential of the high-biomass nickel hyperaccumulator Berkheya coddii for Phytoremediation and phytomining. Journal of Geochemical Exploration, v.60, p.115126, 1997.

ROBINSON, B.; FERNANDEZ, J.; MADEJON, P.; MARANON, T.; MURILLO, J.M.; GREEN, S.; CLOTHIER, B. Phytoextraction: an assessment of biogeochemical and economic viability. Plant and Soil, v.249, p.117-125, 2003. 
ROCOVICH, S.E.; WEST, D.A. Arsenic tolerance in populations of the grass Andropogon scoparius, Science, v.188, p.187-188, 1975.

ROSEN, B. Biochemistry of arsenic detoxification. FEBS Letters, v.529, p.86-92, 2002.

RUGH, C.L.; WILDE, D.; STACK, N.M.; THOMPSON, D.M.; SUMMERS, A.O.; MEAGHER, R.B. Mercuric ion reduction and resistance in transgenic Arabidopsis thaliana plants expressing a modified bacterial merA gene. Proceedings of the National Academy of Science of the USA, v.93, p.3182-/3187, 1996.

SADIQ, M. Arsenic chemistry in soils: an overview of thermodynamic predictions and field observations. Water, Air, and Soil Pollution, v.93, p.117-136, 1997.

SALT, D.E.; SMITH, R.D.; RASKIN, I. Phytoremediation. Annual Review in Plant Physiology and Plant Molecular Biology, v.49, p.643-668, 1998.

SCHAT, H.; LLUGANY, M.; VOOIJS, R.; HARTLEY-WHITAKER, J.; BLEEKER, P.M. The role of phytochelatins in constitutive and adaptive heavy metal tolerances in hyperaccumulator and nonhyperaccumulator metallophytes. Journal of Experimental Botany, v.53, p.2381-2392, 2002.

SCHMOGER, M.E.; OVEN, M.; GRILL, E. Detoxification of arsenic by phytochelatins in plants. Plant Physiology, v.122, p.793-801, 2000.

SCHUTZENDUBEL, A.; ANDREA, P. Plant responses to abiotic stresses: heavy metal-induced oxidative stress and protection by mycorrhization. Journal of Experimental Botany, v.53, p.13511365, 2002.

SHEPPARD, B.S.; CARUSO, J.A.; HEITKEMPER, D.T.; WOLNIK, K.A. Arsenic speciation by ion chroma- tography with induced coupled plasma mass spectrometry detection. Analyst, v.117, p.971975, 1992.

SMITH, S.E.; READ, D.J. Mycorrhizal symbiosis. San Diego: Academic Press, 1997. 605p.

SMITH, E.; NAIDU, R. Arsenic in the soil environment: a review. Advances in Agronomy, v.64, p.149-195, 1998.

SMITH, A.H.; LOPIPERO, P.A.; BATES, M.N.; STEINMAUS, C.M Public health arsenic epidemiology and drinking water standards. Science, v.296, p.2145-2146, 2002.

SNELLER, F.E.C.; VAN HEERWAARDEN, L.M.; KRAAIJEVELDSMIT, F.J.L.; TEN BOOKUM, W.M.; KOEVOETS, P.L.M.; SCHAT, H.; VERKLEIJ, J.A.C. Toxicity of arsenate in Silene vulgaris, accumulation and degradation of arsenate-induced phytochelatins. New Phytologist, v.144, p.223-232, 1999.

SRIVASTAVA, M.; MA, L.Q.; SINGH, N. Antioxidant responses of hyperaccumulator and sensitive fern species to arsenic. Journal of Experimental Botany, v.56, p.1335-1342, 2005.

SUSARLA, S.; MEDINA, V.F.; MCCUTCHEON, S.C. Phytoremediation: An ecological solution to organic chemical contamination. Ecological Engineering, v.18, p.647-658, 2002.

TERRY N, ZAYED AM. 1994. Selenium volatilization by plants. In: FRANKENBERGER, W.T.; BENSON, S. (Ed.) Selenium in the Environment. New York: Marcel Dekker, 1994. p.343-67.

THANABALASINGAM, P.; PICKERING, W.F. Arsenic sorption by humic acids. Environmental Pollution, v.12, p.233-246, 1986.

TU, C.; MA, L.Q.; Effects of arsenic concentrations and forms on arsenic uptake by the hyperaccumulator ladder brake. Journal of Environmental Quality, v.31, p.641-647, 2002.
TU, C.; MA, L.Q. Effects of arsenate and phosphate on their accumulation by an arsenic-hyperaccumulato Pteris vittata L. Plant and Soil, v.249, p.373-382, 2003.

TU, C.; MA, L.Q.; BONDADA, B. Arsenic accumulation in the hyperaccumulator Chinese Brake (Pteris vittata L.) and its utilization potential for phytoremediation. Journal of Environmental Quality, v.31, p.1671-1675, 2002.

TU, C.; MA, L.Q.; ZHANG, W.; CAI, Y.; HARRIS, W.G. Arsenic species and leachability in the fronds of the hyperaccumulator Chinese brake (Pteris vittata L.). Environmental Pollution, v.124, p.223-230, 2003.

TURPEINEN, R.; PANTSAR-KALLIO, M.; HA“GGBLOM, M.; KAIRESALO, T. Influence of microbes on the mobilisation, toxicity and biomethylation of arsenic in soil. Science of the Total Environment, v.236, p.173-180, 1999.

UNITED STATES ENVIRONMENTAL PROTECTION AGENCY USEPA. Arsenic treatment technologies for soil, waste and water. Washington: USEPA, 2002. (Report EPA-542-R-02-004).

VAUGHAN, G.T. The environmental chemistry and fate of arsenical pesticides in cattle tick dip sites and banana land plantations. Melboune: CSIRO Division of Coal Industry, Center for Advanced Analytical Chemistry, NSW, 1993.

WANG, J.R.; ZHAO, F.J.; MEHARG, A.A.; RAAB, A.; FELDMANN, J.; MCGRATH, S.P. Mechanisms of arsenic hyperaccumulation in Perils vittata. Uptake kinetics, interactions with phosphate, and arsenic speciation. Plant Physiology, v.130, p.1552-1561, 2002.

WATANABE, M.E. Phytoremediation on the brink of commercialization. Environmental Science and Technology, v.31, p.182-186, 1997.

WEISSENHORN, I.; LEYVAL, C. Root colonization of maize by a Cdsensitive and a Cd-tolerant Glomus mosseae and cadmium uptake in sand culture. Plant and Soil, v.175, p.233-238, 1995.

WOOLSON, E.A. Emissions, cycling, and effects of arsenic in soil ecosystems. In: FOWLER, B.A. (Ed.).Topics in environmental health. New York: Elsevier, 1983. v.6, p.52-125.

YING, Z.; GUO, L.D.; LIU, R.J. Arbuscular mycorrhizal fungi associated with common pteridophytes in Dujiangyan, southwest China. Mycorrhiza, v.14, p.25-30, 2004.

ZHANG, W.; CAI, Y.; TU, C.; MA, L. Q. Arsenic speciation and distribution in an arsenic hyperaccumulating plant. Science of Total Environment, v.300, p.167-177, 2002.

ZHANG, W.; CAI, Y.; DOWNUM, K.R.; MA, L.Q. Thiol synthesis and arsenic hyperaccumulation in Pteris vittata (Chinese brake fern). Environmental Pollution, v.131, p.337-345, 2004.

ZHAO, F.J.; DUNHAM, S.J.; MCGRATH, S.P. Arsenic hyperaccumulation by different fern species. New Phytologist, v.156, p.27-31, 2002.

ZHAO, F.J.; WANG, J.R.; BARKER, J.H.A.; SCHAT, H.; BLEEKER, P.M.; MCGRATH, S.P. The role of phytochelatins in arsenic tolerance in the hyperaccumulator Pteris vittata. New Phytologist, v.159, p.403-410, 2003.

Received December 19, 2005

Accepted January 02, 2005 